\title{
Paracrine factors relevant to the regulation of spermatogenesis - a review
}

\author{
J. Spiteri-Grech and E. Nieschlag \\ Institute of Reproductive Medicine, University of Münster, Steinfurter Strasse 107, \\ D-48149 Münster, Germany
}

Introduction

In the last two decades, it has become increasingly evident that disturbances of the hypothalamic-pituitary-gonadal axis account for only a small percentage of the cases seen in male infertility clinics. In an attempt to clarify the pathophysiology of idiopathic male infertility and also for the development of new methods for male contraception, researchers have focused on local regulators of intratesticular events (Bartlett et al., 1989; Hamilton and Waites, 1989). The number of factors implicated in paracrine regulation has been steadily increasing and it is essential that the data available are critically examined. The object of this review is to pinpoint the factors of potential or proven physiological significance and to concentrate on the more recent advances made in the field.

The two major areas of activity within the testis centre on steroidogenesis and spermatogenesis. The intratesticular control of steroidogenesis has already been extensively reviewed (Sharpe, 1990) and this paper will therefore concentrate on the regulation of Sertoli cell function and of the cycle of the seminiferous epithelium. A number of questions should be addressed. Does the process of initiation and maintenance of spermatogenesis require additional fine tuning by locally produced substances at the cellular level in the testis? Which of the large number of potential paracrine regulators of spermatogenesis described are of proven physiological significance? In assessing the large body of data available it is necessary to consider which techniques are best adapted to the study of paracrinology and what pitfalls are inherent in these techniques.

\section{Does the process of initiation and maintenance of spermatogenesis require additional fine tuning by locally produced substances at the cellular level in the testis?}

The complicated kinetics of the seminiferous epithelium have long attracted the attention of researchers. At a given time point, a cross-section of the testis reveals adjacent tubules at different stages of the cycle of the seminiferous epithelium. Once the complexity of intratesticular architecture is appreciated, it immediately becomes clear that FSH and testosterone, although generally accepted as the prime regulators of spermatogenesis, can simultaneously maintain the optimal intratesticular environment and also trigger the cascade of events essential for germ cell division and differentiated cell function. For this reason, efforts have been directed to studying intratesticular events. However, evidence supporting the hypothesis of paracrine regulation as an important entity in the testis is predominantly indirect and conclusive evidence is still lacking.

Revised manuscript received 3 March 1992
Idiopathic infertility still represents one of the commonest diagnosis made. In this subgroup of patients with oligoazoospermia or azoospermia, there is no apparent hormonal deficiency: FSH concentrations are often normal or even high. Testicular biopsy often reveals maturation arrest or quantitatively inefficient spermatogenesis. A number of studies have been carried out on the pulsatile secretion of $\mathrm{GnRH}$, and the subsequent release of FSH and LH as well as the gonadal feedback control of gonadotrophin secretion (Wagner et al., 1984; Wagner and von zur Mühlen, 1987). If this represents the major pathophysiology underlying idiopathic male infertility, it would be reasonable to assume that pulsatile administration of physiological doses of LHRH would lead to normal semen parameters. However, in a double blind controlled study, serum FSH returned to normal concentrations but no improvement in semen parameters was observed after pulsatile LHRH administration (Bals-Pratsch et al., 1989).

Other pathological phenomena have been proposed to underlie male idiopathic infertility. For example, isoforms of gonadotrophins, with different glycosylation patterns, altered bioactivity or both (Wang et al., 1987; Jockenhövel et al., 1990; Fauser et al., 1990; Matzkin et al., 1990), could account for the clinical findings outlined above. Alternatively, defects at the FSH or androgen receptor level can be implicated, for example, either at the level of ligand-receptor interaction (Namiki et al. 1984; Buch et al., 1991) or at the post-receptor level. In the latter case, defects may occur at the coupling site with second messenger systems or during protein phosphorylation. Errors in transcription, translation or post-translational modification of peptides can lead to alterations in the internal milieu that are detrimental to spermatogenesis.

Identification of defects occurring at the cellular level within the testis is difficult, however, when so little progress has been made in understanding the sequence of intracellular events and their regulation under normal physiological conditions. The number of factors or peptides isolated from testicular tissue or reported to affect Leydig or Sertoli cell function or spermatogenesis is constantly increasing but these substances have often not been characterized and sequenced. Furthermore, reports concerning the actions of intratesticular peptides are at times contradictory and much controversy has arisen as a result of methodological differences.

\section{Which potential paracrine regulators of spermatogenesis described are of proven physiological significance?}

The extent of the problem encountered in answering this question is immediately evident (Fig. 1). A long and ever growing list of factors implicated in the regulation of spermatogenesis 


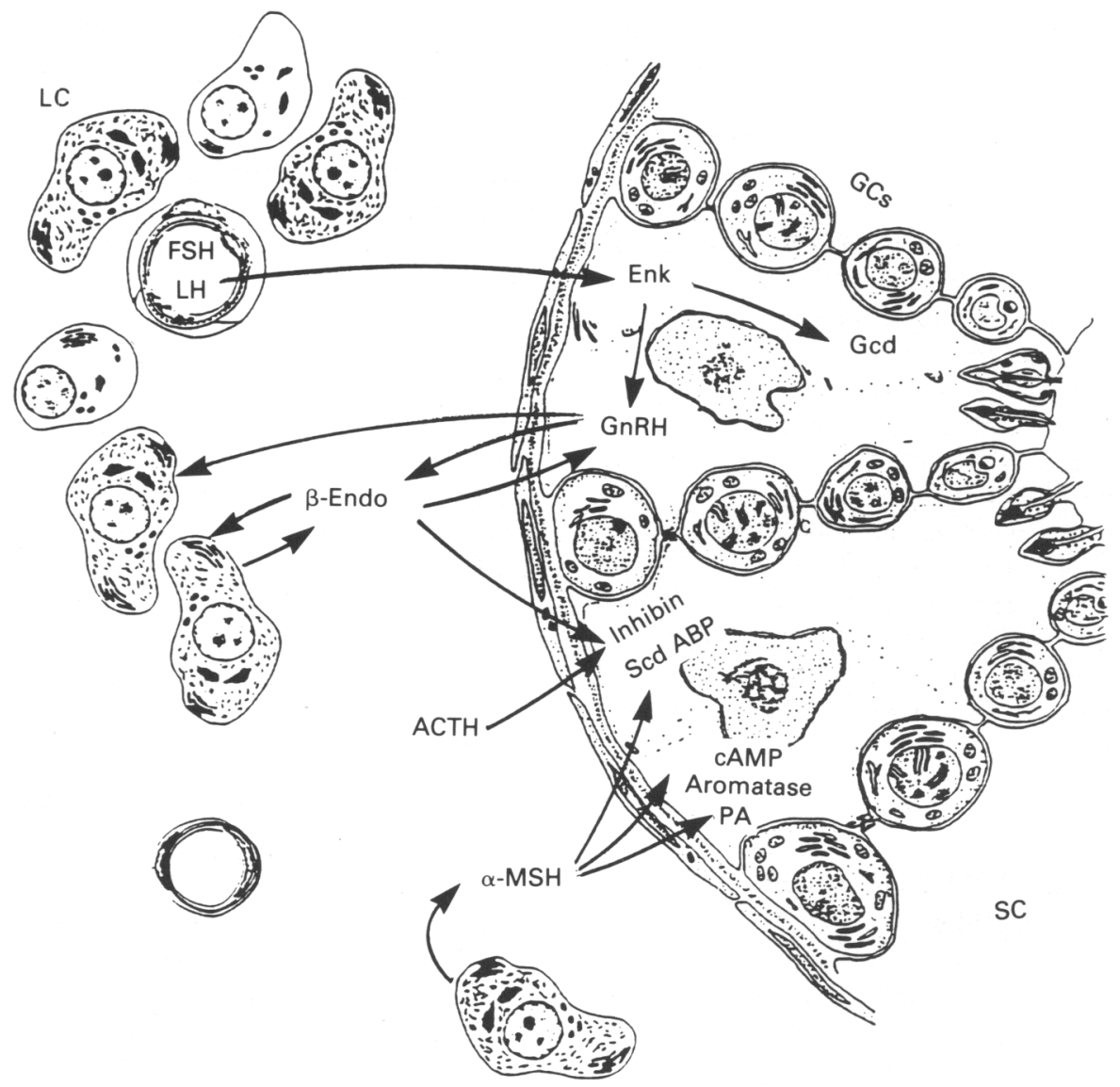

Fig. 1. Intratesticular paracrine and autocrine interactions of opioids. LC: Leydig cell; SC: Sertoli cell; GCs: germ cells; Enk: enkephalins; FSH: follicle-stimulating hormone; LH: luteinizing hormone; GnRH: gonadotrophin-releasing hormone; Gcd: germ cell development; $\boldsymbol{\beta}$-Endo: $\boldsymbol{\beta}$-endorphin; ACTH: adrenocorticotrophic hormone; Scd: Sertoli cell division; ABP: androgen binding protein; cAMP: cyclic adenosine monophosphate; PA: plasminogen activator; $\alpha-\mathrm{MSH}$ : $\alpha$-melanocytic stimulating hormone.

initially overwhelms the reader and immediately leads to the next question. Does the regulation of spermatogenesis require the interaction of all the reported factors or could the majority simply represent 'passive' components of the intratesticular milieu? Histologically, the testis has been divided into different cellular compartments (LeBlond and Clermont, 1952), but the establishment of different microenvironments with a regulated flow of biochemical information between the different compartments is obligatory if a large number of different regulators are to interact to coordinate steroidogenesis and spermatogenesis. This would then involve differential control of regional blood supply, cellular and endothelial permeability, and perhaps alteration in the biochemical half-life of peptides either via structural modification or via the presence of binding proteins. The possibility that such a multifactorial regulatory system operates within the testis has not been conclusively confirmed or refuted and the probability that this system exists will be assessed in the light of available evidence.

A paracrine regulator is by definition a factor produced by one cell type within an organ and having an effect on another cell type within the same organ. The effect at the target cell can involve regulation of differentiated cell function or of cell growth and differentiation.

The roles of testosterone, LHRH-like peptides, interleukin I and other locally produced paracrine regulators of Leydig cell steroidogenesis have already been reviewed (Sharpe, 1990) and will not be discussed further here. A number of enzymes or factors for which no specific intratesticular function relating to either steroidogenesis or spermatogenesis has been identified have been implicated as paracrine regulators. These include renin and angiotensin (Parmentier et al., 1983; Pandey et al., 1984; Strittmater and Snyder, 1984; Jaiswal et al., 1985; Naruse et al., 1985; Velletri et al., 1985; Deschepper et al., 1986; Singh et al., 1987; Millan and Aguilera, 1988; Okuyama et al., 1988; Sealey et al., 1988), caeruloplasmin (Skinner and Griswold, 1983), calmodulin, actins and tubulins (Slaughter et al., 1989), $\alpha_{2}$-macroglobulin (Stahler et al., 1991; Kangasiemi et al., 1992), cyclic protein-2 (Wright et al., 1983; Wright and Luzarraga, 1986; Erickson-Lawrence et al., 1990), gonadotrophin-binding inhibitors (Yang et al., 1976; O'Shaughnessy, 1979; Dias et al., 1981; Rojas et al., 1981; Dias and Reichert, 1983), sulfated glycoproteins-1 and -2 (Kissinger et al., 1982; Sylvester et al., 
1984; Sylvester et al., 1991; Cheng and Bardin, 1987; Cheng et al., 1987; Collard and Griswold, 1987; Cheng et al., 1988; Collard et al., 1988; Roberts et al., 1991; Trasler et al., 1992), plasminogen activator (Lacroix and Fritz, 1982; Hettle et al., 1986; Hettle et al., 1988; Vihko et al., 1987, 1989; Nargolwalla et al., 1990), transferrin (Holmes et al., 1983; Djakiew et al., 1986; Morales et al., 1987; Toebosch et al., 1987; Wauben-Penris et al., 1988; Skinner et al., 1989; Roberts et al,, 1991; Anthony et al., 1991; Spaliviero and Handelsman, 1991), prodynorphins A and $B$ (Douglass et al., 1987; McMurray et al., 1989) as well as thyrotrophin-releasing hormone (Pekary and Rosen, 1982; Pekary et al., 1987), and corticotrophin-releasing hormone (Dave et al., 1984; Yoon et al., 1988). As no specific effect of these substances on the seminiferous epithelium or only effects as carriers have been described so far, their significance as paracrine regulators is yet to be established.

Notwithstanding, even after exclusion of the abovementioned factors, there still remain a substantial number of peptides that have been detected in the testis and for which different functions have been postulated, based predominantly on the results of in vitro studies.

\section{Pro-opiomelanocortin (POMC) and POMC-derived peptides}

By means of in situ hybridization, POMC mRNA has been localized to Leydig cells, spermatocytes and spermatogonia (Chen et al., 1984; Gizang-Ginsberg and Wolgemuth, 1985, 1987; Boitani et al., 1988). Analysis of mRNA expression of POMC-like peptides in the testis revealed mRNAs of various sizes with expression of the authentic POMC mRNA as well as of a smaller form which could arise as a result of different transcription start sites or altered splicing of RNA (Chen et al., 1984; Chen and Madigan, 1987; Jeanotte et al., 1987; Kilpatrick et al., 1987). The significance of these different forms of mRNA is not yet clear and the question naturally arises as to whether the short form of POMC is translated in vivo. Furthermore, direct evidence that the neuropeptide POMC is itself produced locally within the testis is still lacking.

However, the POMC-derived peptides $\beta$-endorphin, adrenal corticotrophic hormone (ACTH) and melanocyte-stimulating hormone (MSH) have been identified in the interstitial fluid and their secretion has been reported by Leydig cells both in vivo and in vitro (Valenca and Negro-Vilar, 1986; Fabbri et al., 1988). These observations and the localization of opiate receptors on Sertoli cells (Boitani et al., 1985; Fabbri et al., 1989) strongly support the potential biological role of these peptides in mediating interactions between Leydig and Sertoli cells. This concept has been further extended following the demonstration that $\beta$-endorphin, $\mathrm{MSH}$ and $\mathrm{ACTH}$ have opposing effects on Sertoli cell function (Fig. 1). $\beta$-Endorphin inhibits FSH-stimulated Sertoli cell division and other FSH-regulated functions via modulation of adenylate cyclase activity (Boitani et al., 1985; Gerendai et al., 1986; Fabbri et al., 1989), whereas ACTH and $\alpha$ MSH stimulate cell division and Sertoli cell function, notably androgen-binding protein (ABP) and inhibin production (Bardin et al., 1984; Boitani et al., 1986). $\alpha$-MSH also stimulates cAMP production and aromatase activity but inhibits plasminogen activator production in cultures of juvenile rat Sertoli cells (Boitani et al., 1988). The opposing effects of these related peptides on Sertoli cell function provide an interesting example of local regulation. However, the time frame in which these interactions occur also requires careful assessment, as cells may develop the capacity to react to different stimuli at different stages of development. In vivo, $\beta$-endorphin concentrations are low in the rat testis before 20 days of age, when division of Sertoli cells occurs, and rise to adult values between 20 and 60 days of age (Adams and Cicero, 1989), thus supporting in vitro evidence for $\beta$-endorphin-mediated inhibition of Sertoli cell division. However, it cannot be assumed that endorphins have a purely passive role in the adult testis inhibiting Sertoli cell division. Endorphins may stimulate GnRH production (Engelhardt, 1989), which in turn can regulate $\boldsymbol{\beta}$-endorphin production in the adult testis (Fabbri et al., 1989). Gonadotrophins and steroids can similarly regulate $\beta$-endorphin production within the testis, thus providing an excellent example of a closed loop system functionally regulating endorphin effects within the testis and simultaneously interacting with endocrine regulatory mechanisms.

\section{Pro-enkephalins and enkephalins}

Pro-enkephalins and enkephalins are another family of neuropeptides identified within the testis. Messenger RNA for the precursor, pro-enkephalin, is present in larger amounts than either POMC- or pro-dynorphin mRNAs in testicular tissue (Douglass et al., 1987) and cDNA transcripts have been localized in both somatic and germ cell lines and also in Sertoli cells (Kilpatrick and Milette, 1986; Kilpatrick et al., 1987). However, pro-enkephalin mRNA has not been found in mouse or rat tumour Leydig cells (McMurray et al., 1989), although enkephalin immunoreactivity has been reported in Leydig cells throughout development (Engelhardt et al., 1986). This discrepancy could be due to de-differentiation of tumour Leydig cells, inhibition of precursor expression or to both factors. A more likely explanation is age-dependent changes in peptide synthesis as suggested by the observation of changes in the expression of proenkephalin mRNA with age (Kilpatrick and Milette, 1986).

The detection of pro-enkephalin mRNA at puberty can be related to the appearance of round spermatids in the testis (Kilpatrick and Milette, 1986). As the signal is localized within round spermatids and pachytene spermatocytes, it is possible that proenkephalin regulates germ cell development. Alternatively, the germ cells produce proenkephalin which then feedbackregulates Sertoli cell function or further maintains germ cell differentiation and maturation. On the basis of pro-enkephalin mRNA analysis alone, however, it is not possible to rule out the possibility that the derivatives of pro-enkephalin and not the precursor itself represent the active elements regulating germ cell division or development on both processes. Enkephalin immunoreactivity has been reported in spermatogonia in juvenile and adult animals, and in primary spermatocytes and Sertoli cells in adult animals (Engelhardt et al., 1986) which would imply that the derivatives may play an active role at least up to the level of primary spermatocytes. However, further analysis of transcription, translation and perhaps even post-translational 
modification of the peptides, as well as localization of receptors to specific cell types is necessary before a clear picture emerges.

Enkephalins, like the POMC-derived peptides, may also play a dual role in the testis, affecting not only germ cell development but also somatic cell function. The production and secretion of testicular LHRH-like factor by Sertoli cells is increased by enkephalins (Saint Pol et al., 1988); the LHRH-like factor in turn interacts with specific Leydig cell receptors modulating steroid production (Sharpe, 1986) and inhibiting $\beta$ endorphin production by Leydig cells (Fabbri et al., 1989). Such a closed loop system of regulation within the testis could serve to maintain the right concentrations of $\beta$-endorphins and enkephalins at a given time. Germ cells or germ cell products, such as pro-enkephalin, could provide an additional level of control which is switched on at the time of appearance of pachytene spermatocytes and round spermatids, i.e. when the metabolic requirements of the seminiferous epithelium may be different. Recently conditioned media from pachytene spermatocytes and round spermatids have been reported to stimulate prepro-enkephalin gene expression in Sertoli cells in vitro (Fujisawa et al., 1992). Although there is no conclusive evidence confirming the presence of such a complex regulatory system in the testis, the in vitro data discussed above together with evidence of hormonal regulation of enkephalin production in the testis (Saint Pol et al., 1986, 1988; Yoshikawa and Aizawa, 1988; Kew and Kilpatrick, 1989) emphasises the potential biological importance of the neuropeptides in the testis.

\section{Oxytocin and vasopressin}

Although oxytocin and vasopressin have been localized immunohistochemically in the testes of different species (Wathes, 1984; Schmale and Richter, 1984; Guldenaar and Pickering, 1985; Kasson et al., 1986; Ang et al., 1991), evidence of intratesticular synthesis was lacking until recently due mainly to methodological problems.

Initial attempts using northern blot hybridization failed to provide evidence for oxytocin gene expression in the testis (Ivell et al., 1986) and the evidence that vasopressin (AVP) is synthesized within the testis was limited until recently to one study where positive dot blotting and hybridization with an AVP probe was possible (Ivell and Morley, 1988). The polymerase chain reaction is a far more sensitive method for the detection of specific mRNA than northern blotting and recently this technique has been effectively applied to the testis (Foo et al., 1991). An authentic RNA transcript identical to that found in the hypothalamus has been identified for oxytocin. However, two novel types of mRNA for testicular AVP have been identified. Exons II and III of the testicular RNA are identical to the corresponding exons of hypothalamic AVP mRNA. However, exon I, which usually encodes AVP and neurophysin-II in the hypothalamus, is not represented within the testis. These novel AVP RNAs are detectable by northern blotting and their expression seems to be developmentally regulated. Subsequent polysome analysis revealed that these messages are probably not translated, and hence not of physiological importance. Although the PCR provides a highly sensitive detection method for messages that are expressed at extremely low levels, there is the danger of amplifying messages coding for sequences or peptides that under normal conditions in vivo are not translated.

However, a number of studies in vifro and in vivo have shown that AVP and oxytocin influence testicular function. Oxytocin has been reported to affect seminiferous tubule contractility in neonatal rats (Worley et al., 1985), hypogonadal mice (Nicholson et al., 1986) and in ethan-1,2-dimethane sulfonate (EDS)-treated rats (Nicholson et al., 1987). Oxytocin and AVP regulate steroidogenesis (Adashi and Hsueh, 1981; Adashi et al., 1984; Sharpe and Cooper, 1987; Tan and Kwan, 1987; Kwan and Grover, 1988; Nicholson et al., 1991) and in addition AVP alters testicular LH and hCG receptor content (Pomerantz et al., 1988). However, if AVP is not synthesized in the testis, the only source of intratesticular AVP is via the circulation and AVP then exerts, by definition, purely endocrine effects on the Leydig cell and is not a paracrine factor. Furthermore, if AVP is derived from the circulation, the question arises as to whether it can cross the blood-testis barrier and hence affect the cells of the seminiferous epithelium.

\section{Inhibins and activins}

In culture, both Leydig and Sertoli cells produce inhibin and activin (de Jong and Robertson, 1985; Tsonis and Sharpe, 1986; Bhasin et al., 1989; Lee et al., 1989; Risbridger et al., 1989; Roberts et al., 1989; Shaha et al., 1989). These two peptides have been postulated to exert opposite effects on the pituitarygonadal axis. However, since the first report on inhibin (McCullagh, 1932), the hormonal regulation and intratesticular actions of these peptides remain a matter of controversy.

Initially, testicular inhibin production as measured by bioassay and later by radioimmunoassay was reported to be regulated by FSH, androstenedione, insulin, epidermal growth factor (EGF) and adenosine (Le Gac and de Kretser, 1982; Conti et al., 1988; Gonzales et al., 1988; Morris et al., 1988) (Fig. 2). However, analysis of mRNA expression revealed that FSH stimulates testicular inhibin $\alpha$-subunit expression but has no effect on $\beta B$-subunit expression in immature rat Sertoli cells in culture (Toebosch et al., 1988; Keinan et al., 1989; Klaij et al., 1990; Pineau et al., 1990). However, FSH has been generally accepted as the prime regulator of inhibin production which subsequently feedback-regulates pituitary FSH production. The concept that other hormones or factors primarily regulate $\beta$-subunit expression was therefore new. An alternative explanation may be that immature cells cannot produce these peptides. Stagespecific expression of inhibin $\alpha$ - and $\beta$-subunits has been demonstrated in the adult testis using both immunohistochemical techniques and northern blot hybridization (Merchenthaler et al., 1987; Rivier et al., 1988; Bhasin et al., 1989), thus providing further evidence for age-dependent expression of both subunits and peptide production. Furthermore, inhibin secretion from adult rat seminiferous tubules in culture varies according to the stage of the seminiferous epithelium, changes that are detected by both radioimmunoassay and bioassay (Gonzales et al., 1989). In vitro studies using Sertoli-germ cell cultures from 20-day-old rats have further demonstrated that germ cells, particularly early spermatids, stimulate inhibin mRNA expression 


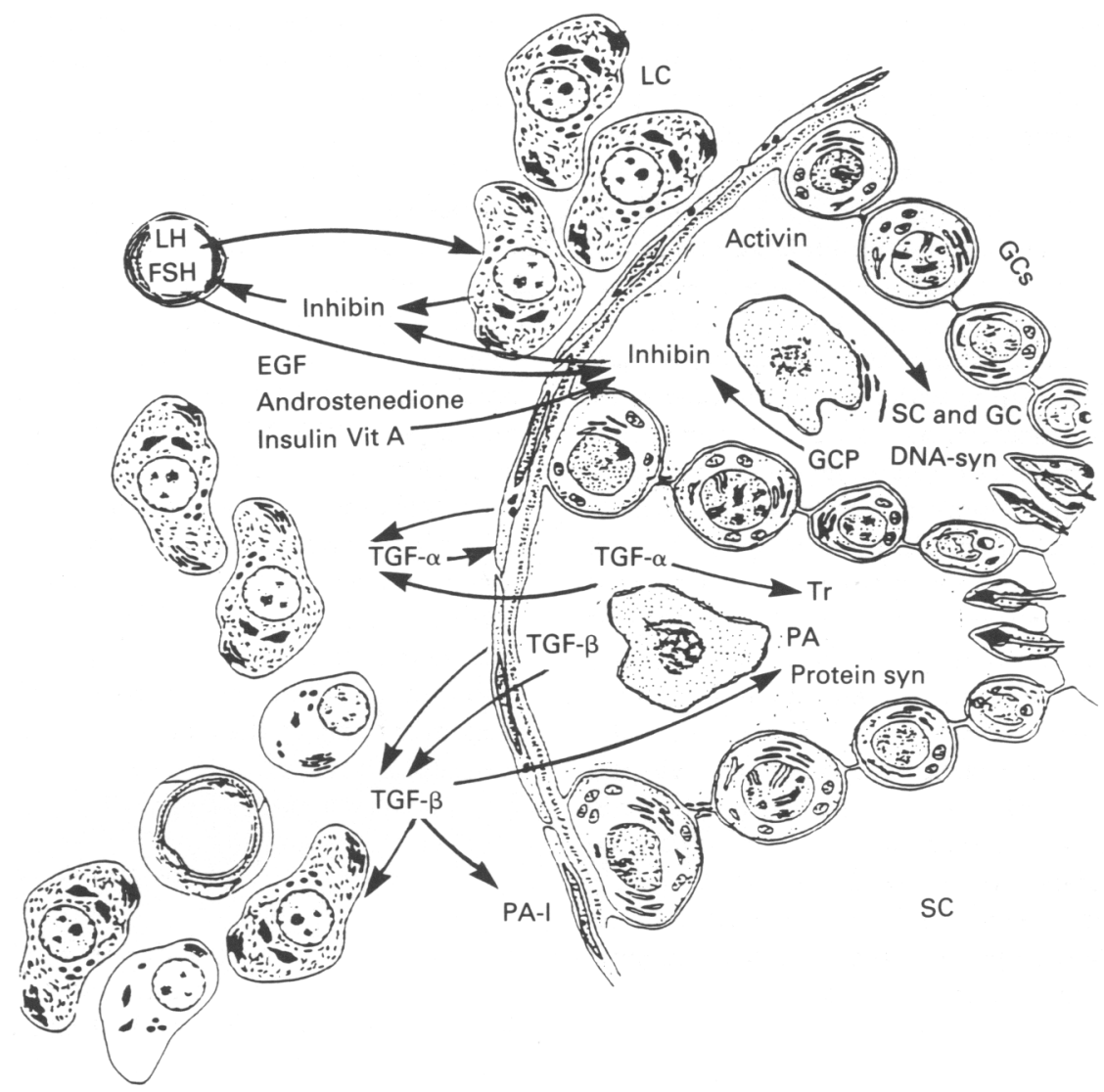

Fig. 2. Inhibin, activin and the transforming growth factors (TGF- $\alpha$ and TGF- $\beta$ ) and their role in the paracrine regulation of intratesticular events. LC: Leydig cell; SC: Sertoli cell; GCs: germ cells; LH: luteinizing hormone; FSH: follicle-stimulating hormone; SC and GC DNA-syn: Sertoli and germ cell DNA synthesis; GCP: germ cell products; EGF: epidermal growth factor; Vit $A$ : vitamin A; Tr: transferrin; PA: plasminogen activator; PA-I: plasminogen activator inhibitor; Protein syn: protein synthesis.

and immuno- and bioactive inhibin secretion in Sertoli cells (Pineau et al., 1990). However, in vivo, methoxyacetic acid treatment of adult rats with depletion of pachytene spermatocytes leads to an increase in inhibin secretion by Sertoli cells, whereas absence of late spermatids is clearly associated with a decrease in inhibin secretion by Sertoli cells and in circulating inhibin concentrations (Allenby et al., 1991). One possible explanation for this discrepancy between in vitro and in vivo findings is that the cultured Sertoli cells were harvested from immature rat testes, whereas adult mature rats were used in the in vivo study. The demonstration of developmental changes in the expression of testicular inhibin mRNA and the secretion of the peptide (Keeping et al., 1990) strongly supports this hypothesis and further emphasizes the pitfalls of extrapolating observations made in an in vitro system using immature cells to establish the physiological relevance of a given peptide in the adult in vivo.

There is sufficient evidence in the literature for both the production and secretion of inhibin by Sertoli cells, although the effect of different hormones and germ cells or germ cell products on synthesis and secretion do differ throughout development. The role of inhibin in the feedback regulation of pituitary FSH secretion has been extensively studied. Inhibin must be secreted from the testis, the major site of production of the peptide, into the circulation to affect pituitary FSH secretion. Bidirectional secretion of inhibin by Sertoli cells in culture with preference for the luminal direction has been reported (Janecki et al., 1988), whereas apically secreted inhibin is reabsorbed from the seminiferous tubule fluid into the blood in the region of the rete testis (Maddocks and Sharpe, 1989; Maddocks and Sharpe, 1990). However, despite FSH stimulation of inhibin secretion in vitro, the demonstration of a straightforward relationship between serum inhibin and FSH concentrations has been more difficult (Culler and Negro-Vilar, 1988; de Kretser et al., 1989; Weinbauer et al., 1989; Maddocks and Sharpe, 1990). Lack of specificity of the antisera available for the measurement of inhibin, interspecies variations and differential developmental regulation of inhibin secretion (Rivier ef al, 1988; Burger et al., 1988; Abeyawardene et al., 1989; Keeping et al., 1990) could perhaps account for the conflicting reports. Significant suppression of serum FSH concentrations has, however, been achieved following the administration of recombinant inhibin to castrated rats (Robertson et al., 1991), supporting the hypothesis that inhibin can act as a feedback regulator of pituitary FSH secretion.

The clinical observation of high concentrations of FSH in serum of patients with oligozoospermia and idiopathic 
infertility has led to unsuccessful attempts to correlate concentrations of inhibin in serum to the degree of testicular damage (de Kretser et al., 1989). As discussed above, germ cells modulate inhibin production by Sertoli cells and in patients with biopsy-proven Sertoli-cell-only syndrome or maturation arrest of spermatogenesis and high concentrations of $\mathrm{FSH}$, changes in inhibin concentrations may be expected but have not been conclusively demonstrated. The development of more specific and sensitive assays for inhibin may eventually reveal disturbances in the serum inhibin profiles of selected patients. However, factors regulating the secretion of testicular inhibin into the circulation may modulate serum profiles such that any direct correlation to circulating FSH concentrations in a given sample taken at one time point is masked. A lag phase of as yet undefined duration may be present, as suggested by the observation that 4-8 h elapse after a single injection of recombinant inhibin to castrated rats before a fall in concentration of FSH in serum is observed (Robertson et al., 1991).

Within the testis, the precise function of inhibin still needs to be established. The possibility that inhibin could interfere with FSH binding to its receptors in the testis has been raised, but not substantiated (Vijayalakahmi et al., 1980). Inhibin has, however, been shown to inhibit the incorporation of labelled thymidine into testicular DNA both in vitro and in vivo (Franchimont et al., 1981; van Dissel-Emiliani et al., 1989). Inhibin, in addition to the previously postulated role in the feedback regulation of pituitary FSH secretion, may therefore also restrict FSH action at the testicular level. After the demonstration of a definite stimulatory effect of activin on pituitary cell FSH secretion and on circulating FSH concentrations in macaques and rats in vivo (Ling et al., 1986; McLachlan et al., 1989; Schwall et al., 1989), the possibility that activin acts to oppose inhibin action within the testis has been investigated. Activin was shown to stimulate incorporation of $\left[{ }^{3} \mathrm{H}\right]$ thymidine into Sertoli and germ cell cocultures from 21-day-old rats, and also to increase the $4 \mathrm{C} \mathrm{popu-}$ lation of cells as shown by flow cytometric analysis, whereas inhibin does not affect either in this experimental model (Mather et al., 1990; Mather and Krummen, 1992). In contrast, intratesticular injections of inhibin result in a significant reduction in spermatogonial numbers in the testes of adult mice and Chinese hamsters (van Dissel-Emiliani et al., 1989). Although the presence of interspecies variation in the response to a peptide could account for these conflicting reports, the different observations are probably due to the experimental models used in these two studies.

The demonstration that mRNA for $\alpha$-, $\beta$ A- and $\beta B$-subunits is present in Sertoli cells but not in germ cells (Bhasin et al., 1989; Roberts et al., 1989; Shaha et al., 1989; Kaipia et al., 1991, 1992) and is expressed in a stage-specific manner supports a paracrine role for activin and inhibin in Sertoli-germ cell interaction. However, inhibin $\beta A$-subunits have been localized immunohistochemically to developing germ cells (Shaha et al., 1989) with the result that autocrine effects of the peptides on germ cells cannot be excluded. As the level of mRNA expression may be too low to be detected by northern blot analysis, application of ribonuclease protection assays or of PCR could eventually help identify the presence or absence of inhibin or activin mRNA subunits in germ cells. An important limitation to the demonstration of both $\alpha$ and $\beta$ mRNA subunits in a given tissue or cell population is that the presence of mRNA for both subunits makes it impossible to distinguish between activin and inhibin production.

The cloning of the activin receptor (Mathews and Vale, 1991) was followed by the localization of a $4 \mathrm{~kb}$ mRNA for the activin receptor to isolated pachytene spermatocytes and round spermatids (de Winter et al., 1992). Two activin receptor mRNAs $(4 \mathrm{~kb}$ and $6 \mathrm{~kb}$ ) have been identified in Sertoli cells from both immature and mature rats with low levels of expression evident in Leydig cells (de Winter et al., 1992). The biological significance of the different messages for the activin receptor has yet to be investigated. One of the two messages could represent a transcript that is not translated as has been described in other instances (Ivell, 1992). However, alternative mRNA splicing has been shown to result in different activin receptor isoforms, belonging to the serine/threonine kinase receptor family, with species that differ in ligand binding affinity, cytoplasmic domain structure or both (Attisano et al., 1992). Additional selectivity of activin and inhibin actions at a given time may be conferred through alteration of receptor gene expression and translation. Furthermore, identification of follistatin as an activin-binding protein in both the gonads and the pituitary (de Paolo et al., 1991) suggests another possible mechanism for regulating activin actions.

\section{Growth factors}

Growth factors have been acknowledged to regulate somatic and germ cell division but recently it has become evident that growth factors also influence differentiated cell function. A number of extensive reviews discussing the role of different growth factors in the regulation of testicular function and the characteristics of these growth factors have been published by Bellvé and Zheng (1989) and Skinner (1991). The list of growth factors implicated in testicular paracrine regulation now includes Sertoli cell secreted growth factor (SCSGF), seminiferous growth factor (SGF), epidermal growth factor (EGF), transforming growth factors $\alpha$ and $\beta$ (TGF- $\alpha$ and $-\beta$ ), insulin-like growth factors I and II (IGF-I and -II), acidic and basic fibroblast growth factors (aFGF and bFGF), $\beta$-nerve growth factor $(\beta$ NGF), platelet-derived growth factor (PDGF), and interleukin 1 (IL-1). This section of the review will therefore concentrate solely on those growth factors for which an effect on Sertoli cell function and Sertoli-germ cell interactions has been postulated or documented.

A prerequisite for the identification of growth factors important in the regulation of the seminiferous epithelial compartment should be the demonstration of the synthesis and secretion of the peptide in this compartment, demonstration of an effect or effects on differentiated cell function or somatic or germ cell division or on both, and the localization of receptors on the postulated target cells. Analysis of the literature reveals that of the above-mentioned growth factors, TGF- $\alpha$ and $-\beta$, EGF, IGF-I and IGF-II are the only factors that fulfil these criteria.

\section{Transforming growth factor a (TGF-a)}

TGF- $\alpha$ mRNA expression has been demonstrated in isolated peritubular and Sertoli cells (Skinner et al., 1989) and secretion 
of TGF- $\alpha$ by both cell types occurs in vitro. However, TGF- $\alpha$ acts predominantly in an autocrine fashion inducing proliferation and mixed cell aggregation solely in rat peritubular cells and not in Sertoli cells (Skinner et al., 1989). The biological significance of these findings is not clear, but the presence of receptors for TGF- $\alpha$ or EGF on rat peritubular cells further supports the concept that TGF- $\alpha$ can regulate peritubular cell function. Although Skinner and co-workers could not demonstrate binding of radiolabelled EGF to TGF- $\alpha$ receptors on Sertoli cells, peritubular-Sertoli cell co-cultures produce transferrin on stimulation with TGF- $\alpha$ (Skinner et al., 1989), an effect which they suggest is mediated by TGF- $\alpha$-induced production of a paracrine factor, such as peritubular modifying substance (PmodS), which subsequently stimulates transferrin production by Sertoli cells (Norton and Skinner, 1989; Anthony et al., 1991). However, direct effects of TGF- $\alpha$ on Sertoli cells may be possible as other groups have immunohistochemically localized the receptor to Sertoli cells in rats (Suarez-Quian et al., 1989) and to the interstitium in humans (Stubbs et al., 1990). Final confirmation of the presence or absence of EGF/TGF- $\alpha$ receptor synthesis by Sertoli cells has to await the application of sensitive hybridization protocols or of the polymerase chain reaction to the problem.

\section{Transforming growth factor- $\beta$ (TGF- $\beta$ )}

Five different isoforms of TGF- $\beta$, which are structurally related to inhibin and activin, have been isolated from different tissues (Deuvel, 1987; Sporn and Roberts, 1990). Within the testis, TGF- $\beta 1$ mRNA has been detected in peritubular cells and Sertoli cells, whereas peritubular cells also contain mRNA for TGF- $\beta 2$ in the immature rat testis (Skinner and Moses, 1989). Secretion of the isoforms by these cells in culture has not been demonstrated nor have receptors for TGF- $\beta$ been localized within the testis. TGF- $\beta$ has no effect on secretion of transferrin by Sertoli cells but promotes an increase in the production of radiolabelled secreted proteins by peritubular cells, and also stimulates peritubular cell migration and colony formation in culture (Skinner and Moses, 1989). This finding may be taken as indirect evidence for the presence of receptors for TGF- $\beta$ on peritubular cells, but the possibility that other cell types contaminate the peritubular cell culture or of nonspecific interaction of TGF- $\beta$ with other receptors cannot be excluded. Definite localization of the receptor is essential, as the lack of effects on Sertoli cell transferrin production does not exclude other TGF- $\beta$-mediated effects on the Sertoli cell and the presence of a receptor on Sertoli cells would stimulate further research in this area.

In other systems such as the ovary, TGF- $\alpha$ and TGF- $\beta$ have been reported to have diametrically opposite effects on cell division and differentiated cell function and a similar role may be postulated for the TGFs in the testis. However, although TGF- $\alpha$ stimulates peritubular cell proliferation, TGF- $\beta I$ had no effect either on peritubular or Sertoli cell proliferation in cells isolated from the mid-pubertal stage of development (Skinner and Moses, 1989). Re-examination of the expression of the growth factors at different stages throughout development revealed that TGF- $\beta 2$ expression occurs in both peritubular and Sertoli cells in the immature testis, whereas TGF- $\beta 3$ is expressed by both cell types throughout development. Stimulation of Sertoli cells with FSH downregulates TGF- $\beta 2$ expression (Mullaney $e$ t al., 1991) which woud otherwise play a role as a growth inhibitor at the time of initiation of active germinal cell growth. In the adult testis, TGF- $\beta 1$ immunoreactivity has been observed in Sertoli cells, spermatocytes and spermatids at about the time when meiosis occurs, whereas TGF- $\beta 2$ immunoreactivity is present only in post-meiotic germ cells, suggesting a role for this isoform in spermatid differentiation (Teerds and Dorrington, 1992) in the adult rat. Although there is no firm evidence supporting interactions between TGF- $\alpha$ and TGF- $\beta$ effects on somatic and germ cell populations in the testis in vivo at a specific stage of development, further elucidation of the interactions between the different isoforms of TGF- $\beta$ may provide insight into the factors co-ordinating spermatogenesis and spermiogenesis in the seminiferous epithelium.

\section{Epidermal growth factor (EGF)}

Extirpation of mouse submaxillary glands results in a very low concentration of EGF in serum and impairment of spermatogenesis which is reversible in the presence of EGF (Tsutsumi et al., 1986). Russell et al. (1990) were unable to quantitatively reproduce these effects, possibly owing to methodological differences in the morphological analysis of the testis. However, there is considerable evidence that EGF stimulates biochemical responses in Sertoli cells (Mallea et al., 1986; Perez-Infante et al., 1986; Spaliviero and Handelsman, 1991). Since EGF and TGF- $\alpha$ have a high degree of similarity in sequences (Savage et al, 1972) and interact at one and the same receptor (Downward et al., 1984), the reported effects could simply reflect an artefact due to EGF interaction at a receptor that normally sees only TGF- $\alpha$. This hypothesis is supported by the inability to detect mRNA for EGF using a human cDNA probe in both Sertoli and peritubular cells (Skinner et al., 1989). However, if the message for the growth factor is expressed only at low levels, the application of nuclease protection assays or PCR is essential before EGF is excluded as a paracrine regulator of testicular function. In addition, application of immunohistochemical techniques to the localization of EGF and TGF in the testis could help resolve the question, if antibodies of sufficient sensitivity and specificity are available. This line of investigation would be worth following, as in a study in vivo using an antiserum against EGF which has no crossreactivity with TGF- $\alpha$, stage-dependent changes in intratesticular EGF or an EGF-like peptide have been reported in vitamin-A-deficient rats resubstituted with retinol and exhibiting stage-synchronization of spermatogenesis (Bartlett et al., 1990).

The presence of EGF/TGF- $\alpha$ binding sites on Leydig, Sertoli, myoid and endothelial and different germ cell populations have been reported (Morris and Mather, 1984; Kris et al., 1985; Suarez-Quian et al., 1989; Stubbs et al., 1990) in various animal species. Specificity of the antibodies for different epitopes on the EGF receptor, interspecies variations and age-dependent changes in the expression of EGF receptor could account for the different results obtained by the various groups.

Given the problems outlined above, it is not surprising that there is a lack of data on the effect of EGF in humans. It has been claimed that there is no correlation between seminal plasma EGF concentrations and age of the donor, number of spermatozoa, motility or period of sexual abstinence (Elson et al., 1984). There 
is also no difference in seminal plasma EGF concentrations in relation to sperm density, progressive motility of azoospermia in infertile compared with fertile men (Richards $e$ t al., 1988). This could be due to the fact that the major proportion of the EGF in seminal plasma is from another source such as the prostate. Ethical reasons prevent studies on testicular EGF regulation in humans but the use of animal models to study the questions raised should elucidate the role of EGF in the regulation of spermatogenesis. Furthermore, studies in vivo of the stimulatory effect of EGF on Leydig cell steroidogenesis reported in vitro (Syed et al., 1991) are obviously lacking.

\section{Insulin-like growth factor-I (IGF-I)}

There is evidence from several sources that IGF-I is present in the testis (Handelsman et al., 1985; Benahmed et al., 1987; Smith et al., 1987) and mRNA transcripts for IGF-I have been identified among testis poly [A+] RNA by northern blot analyses (Casella et al., 1987). The peptide has been identified immunohistochemically in and shown to be secreted by Leydig and Sertoli cells (Handelsman et al., 1985; Smith et al., 1987; Vanelli et al., 1988), in immature rats and in adult humans (Hansson et al., 1989) and to be present in primary spermatocytes in adult rats and humans (Vanelli et al., 1988; Hansson et al., 1989). A membrane receptor for IGF-I designated IGF type I receptor has been characterized and localized to Sertoli cells (Borland $e$ t al., 1984; Vanelli et al., 1988), Leydig cells (Handelsman et al., 1985) and secondary spermatocytes and early spermatids (Tres $e t$ al., 1986; Vanelli et al., 1988). It could, therefore, be postulated that IGF-I plays an autocrine role in regulating Sertoli and Leydig cell function and may play a paracrine role in the cycle of the seminiferous epithelium.

Tissue IGF-I production is probably controlled by factors other than GH ( $\mathrm{D}^{\prime}$ Ercole et al., 1984). FSH, LH or testosterone, alone or in combination, which appear to play a major role, as well as EGF and FGF, have been shown to regulate testicular IGF-I mRNA expression and peptide content in both immature and mature rats (Tres et al., 1986; Chatelain et al., 1987; Closset et al., 1989; Spiteri-Grech et al., 1991a, b).

\section{Insulin-like growth factor-II (IGF-II)}

Little is known about the production of IGF-II in the testis. The gene for IGF-II is not transcribed at detectable amounts in the rat testis when northern blot analysis is used (Murphy et al., 1987). The physiological effects of IGF-II observed in the testis therefore probably depend on the interaction of the serum protein with endogenous cellular receptors, although the application of newer and more sensitive techniques should be used to address this question once more.

A type II membrane receptor $(230 \mathrm{kDa})$ similar to the cationindependent mannose-6-phosphate receptor is present in testicular membrane preparations, specifically on Sertoli cell membranes (Borland et al., 1984; Morgan et al., 1987; Taylor et al., 1987; Roth, 1988). Mouse pachytene spermatocytes and round spermatids have predominantly cation-dependent receptors $(46 \mathrm{kDa})$ with low concentrations of the cation-independent form but more cell surface expression of the latter type than in Sertoli cells, which synthesize larger amounts of the cationindependent form but express very little on the cell surface (O'Brien et al., 1988). Pachytene spermatocytes and spermatids (steps 1-8) are capable of mannose-6-phosphate receptor mediated endocytosis and lysosomal enzyme processing, as shown by the accumulation of $\left.{ }^{125} \mathrm{I}\right]$-labelled lysosomal enzymes containing mannose-6-phosphate (O'Brien et al., 1988). However, the question of whether the IGF-II/mannose-6-phosphate receptors on the germ cells are accessible to serum IGF-II or whether they transport mannose-6-phosphate containing lysosomal enzymes secreted by Sertoli cells into the central compartment of the seminiferous epithelium remains unanswered. Other functions reported include IGF-II-induced increases in Sertoli cell transferrin synthesis (Skinner and Griswold, 1982; Spaliviero and Handelsman, 1991) and increased lactate and protein production (Borland et al., 1984). These effects may represent artefacts generated via interaction of IGF-II with type I receptors or may be specific biochemical effects mediated via interaction with the type II receptor. The latter possibility implies receptor linkage to different second messenger systems that mediate different cellular responses. Further studies concerning activation of second messenger systems after IGF binding to the different receptor types may clarify this.

Because of the methodological problems and the various affinities of the two types of receptor for the IGFs and insulin, the biological effects of the two factors on the testis should be discussed together (Fig. 3). Via interaction with type I receptors, IGF-I, IGF-II and insulin increase thymidine incorporation into Sertoli cell cultures prepared from 13-day-old rat testes, whereas IGF-II stimulates leucine incorporation into protein probably through interaction with type II receptors present on Sertoli cells (Borland et al., 1984). FSH, IGF-I and insulin also stimulate Sertoli cell glucose uptake and lactate production (Mita et al., 1985; Oonk et al., 1985; Oonk, 1987; Oonk and Grootegoed, 1988). IGF-I may exert a priming effect on the capacity of the Sertoli cell to respond to FSH and furthermore stimulate mitogenesis in both immature Leydig and Sertoli cells. It can be argued that this is not a specific effect since insulin has similar effects but supraphysiological concentrations of insulin are necessary to achieve this and probably the growth-promoting effect of insulin is the result of interaction with tissue IGF-I receptors (Saez et al., 1988). Similarly, pretreatment of porcine Leydig cells with nanomolar concentrations of IGF-I (or micromolar concentrations of insulin) increases the hCG receptor number and enhances steroidogenesis both directly (Lin et al., 1986) and in response to gonadotrophins (Kasson and Hsueh, 1987). An additional level of control operates through hCG and LH regulation of Leydig cell IGF-I receptors (Lin et al., 1988; Nagpal et al., 1991). An LH-regulated IGF-mediated paracrine loop therefore exists in the testis. Whether a similar interaction between FSH, IGF-I and Sertoli cells is present and whether IGF-I produced by Sertoli cells is also secreted into the central compartment of the seminiferous tubule, thereby affecting germ cell differentiation, remains to be established. Recently, IGFs have been reported to stimulate apical transferrin secretion preferentially in a bicameral Sertoli cell culture system (Spaliviero and Handelsman, 1991), which provides evidence in support of IGF-mediated effects on germ cell differentiation. In rat Sertolispermatogenic cell co-cultures, immunoreactive IGF-I is associated with pachytene spermatocytes but not with spermatogonia or early meiotic prophase spermatocytes. In vivo, a strong and positive correlation between testicular IGF-I content and the presence of pachytene spermatocytes and spermatids has been 


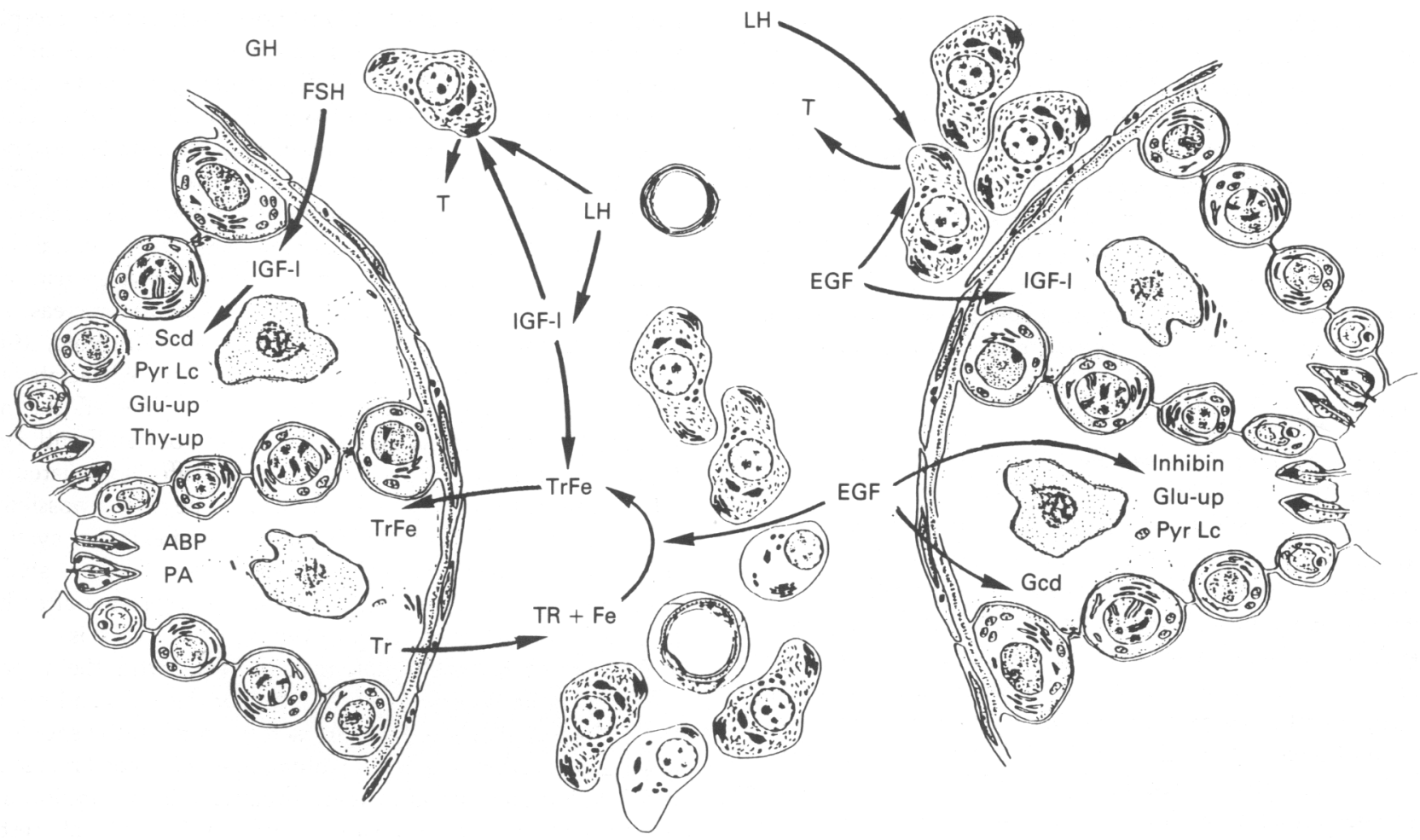

Fig. 3. The effects of insulin-like growth factor-I (IGF-I) and epidermal growth factor (EGF) and the factors regulating their production at the cellular level in the testis. GH: growth hormone; LH: luteinizing hormone; FSH: follicle-stimulating hormone; T: testosterone; Scd: Sertoli cell division; Pyr Lc: pyruvate lactate metabolism; Glu-up: glucose uptake; Thy-up: thymidine uptake; ABP: androgen-binding protein; PA: plasminogen activator; $\mathrm{Tr}$ : transferrin; Fe: iron; $\mathrm{Tr}-\mathrm{Fe}$ : transferrin-iron complex; Gcd: germ cell development.

shown (Spiteri-Grech et al., 1992), further stressing the potential biological importance of this peptide in regulating the seminiferous epithelium.

The presence of binding sites and the effect of various in vitro and in vivo treatments on IGF-I mRNA expression and peptide secretion strongly support a paracrine/autocrine role for IGF-I in the regulation of Sertoli-germ cell interactions. The role of the different IGF-binding proteins in modulating the actions of IGF-I and -II is also attracting increasing attention. Transcripts for IGFBP-3, -4 and -5 have been identified in the rat testis (Shimasaki et al., 1989, 1990, 1991; Albiston and Herington, 1992). Peritubular cells in culture synthesize predominantly IGFBP-2, whereas Sertoli cells secrete mainly IGFBP-3 (Smith et al., 1990). Differential regulation of IGFBP-3 and IGF-I secretion by FSH-stimulated Sertoli cells has been reported (Cailleau et al., 1990; Smith et al., 1990). The presence of a local feedback loop with FSH stimulating IGF-I production but inhibiting IGFBP-3 production which in turn may be stimulated by rising concentrations of bioactive IGF-I within the testis can therefore be postulated. Future research concerning the binding proteins may provide insights into how the biological availability of a given peptide is regulated at a given time under specific conditions within the testis.

\section{Conclusion}

In conclusion, paracrine regulation of testicular function is an interesting concept, but the nature of testicular architecture and the multiple interactions occurring at a cellular level makes design of studies and interpretation of data generated difficult. Application of molecular biology techniques may help to answer some of the questions raised by this article, but caution is just as necessary in the interpretation of data generated by these methods as by the more traditional techniques previously used by morphologists and endocrinologists. The best approach to address the question of paracrine regulation of seminiferous epithelial function remains the combination of old and new methods in in vitro and in vivo studies. Observation of a given effect in an in vitro system using cells isolated from immature animals should certainly not lead to extrapolation to the adult animal in vivo. The question of differential regulation of gene expression throughout development and correlation to the development of specific functions or characteristics may provide important clues to the local regulation of testicular function. Immunohistochemistry, mRNA expression, and in situ hybridization suggest synthesis of a peptide but finally the demonstration of specific effects of the factors isolated from testicular tissue and subsequently characterized is essential. As a result of methodological and ethical problems, we are still a long way from identifying new pathophysiological mechanisms underlying male infertility. LH and FSH are generally acknowledged as prime regulators of male reproductive function, but increasing recognition of the importance of endocrine and paracrine interaction for normal testicular function is a step in the right direction. For the POMC-derived peptides, EGF/TGF$\alpha$, the inhibin - activin family and the IGFs, there is convincing evidence for such interactions. Time and effort are, however, 
required before a clearly defined paracrine system integrating these and other factors into the complex regulation of testicular function is established.

The authors gratefully acknowledge the support of the Max Planck Society and the Deutsche Forschungsgemeinschaft (Ni 130/11).

\section{References}

Abeyawardene SA, Vale WW, Marshall GR and Plant TM (1989) Circulating inhibin $\alpha$ concentrations in infant, prepubertal and adult male rhesus monkeys (Macaca mulatta) and in juvenile males during premature initiation of puberty with pulsatile gonadotrophin releasing hormone treatment Endocrinology 125 250-256

Adams ML and Cicero TJ (1989) The ontogeny of immunoreactive beta-endorphin and beta-lipotropin in the rat testis Life Sciences 44 159-166

Adashi EY and Hsueh AJW (1981) Direct inhibition of testicular androgen biosynthesis reveals antigonadal activity of neurohypophyseal hormones Nature $293650-652$

Adashi EY, Tucker E and Hsueh AJW (1984) Direct regulation of testicular steroidogenesis by neurohypophysial hormones Joumal of Biological Chemistry 259 5440-5446

Albiston AL and Herington AC (1992) Tissue distribution and regulation of insulin-like growth factor binding protein 3 (IGFBP-3) mRNA in the rat: comparison with IGF-I mRNA expression Endocrinology 130 497-502

Allenby G, Foster PMD and Sharpe RM (1991) Evidence that secretion of immunoactive inhibin by seminiferous tubules from the adult testis is regulated by specific germ cell types: correlation between in vivo and in vitro studies Endocrinology 128 467-476

Ang HL, Ungefroren H, de Bree F, Foo NC, Carter D, Burbach JP, Ivell R and Murphy D (1991) Testicular oxytocin gene expression in seminiferous tubules of cattle and transgenic mice Endocrinology 128 2110-2117

Anthony CT, Rosselli M and Skinner MK (1991) Actions of the testicular paracrine factor (P-Mod-S) in Sertoli cell transferrin secretion throughout pubertal development Endocrinology 129 353-360

Attisano L, Wrana JL, Cheifetz S and Massague J (1992) Novel activin receptors: distinct genes and alternative $\mathrm{mRNA}$ splicing generate a repertoire of serine/ threonine kinase receptors Cell 68 97-108

Bals-Pratsch M, Knuth UA, Hönigl W, Klein HM, Bergmann M and Nieschlag E (1989) Pulsatile GnRH therapy in oligozoospermic men does not improve seminal parameters despite decreased FSH levels Clinical Endocrinology30 549-560

Bardin CW, Shaha C, Mather J, Salomon Y, Margioris AN, Liotta AS, Gerendai I, Chen CL and Krieger DT (1984) Identification and possible function of proopiomelanocortin-derived peptides in the testis Annals of the New York Academy of Sciences 438 346-364

Bartlett JMS, Jockenhövel F and Nieschlag E (1989) New approaches to the pathophysiology of male infertility. A meeting report International joumal of Andrology 12 240-249

Bartlett JMS, Spiteri-Grech J and Nieschlag E (1990) Regulation of insulin-like growth factor I and stage-specific levels of epidermal growth factor in stage synchronized rat testes Endocrinology 127 747-758

Bellve AR and Zheng W (1989) Growth factors as autocrine and paracrine modulators of male gonadal functions Joumal of Reproduction and Fertility $\mathbf{8 5}$ 771-793

Benahmed M, Morera AM, Chauvin M and de Peretti E (1987) SmC/IGF-I as a possible intratesticular regulator of Leydig cell activity Molecular and Cellular Endocrinology 50 169-178

Bhasin S, Krummen KA, Swerdloff RS, Morelos BS, Kim WH, diZerega GS, Ling N, Esch F, Shimasaki S and Toppari J (1989) Stage-dependent expression of inhibin $\alpha$ - and $\beta$-subunits during the cycle of the rat seminiferous epithelium Endocrinology 124 987-991

Boitani C, Chen CL, Margioris AN, Gerendai I, Morris PL and Bardin CW (1985) Pro-opiomelanocortin-derived peptides in the testis: evidence for a possible role in Leydig and Sertoli cell function Medical Biology 63 251-258

Boitani C, Mather IP and Bardin CW (1986) Stimulation of adenosine $3^{\prime} 5^{\prime}$ monophosphate production in rat Sertoli cells by alpha-melanotropinstimulating hormone (alpha MSH) and des-acetyl alpha MSH Endocrinology $1181513-1518$

Boitani C, Chen CL, Canipari R and Bardin CW (1988) Expression of the proopiomelanocortin (POMC) gene in rat testicular germ cells and the response of Sertoli cells to POMC-derived peptides. In The Molecular and Cellular Endocrinology of the Testis Eds BA Cooke and RM Sharpe. Serono Symposia Publications, Vol 50 pp 303-309. Raven Press, New York

Borland K, Mita M, Oppenheimer CL, Blinderman LA, Massague J, Hall PF and Czech MP (1984) The actions of insulin-like growth factors I and II on cultured Sertoli cells Endocrinology 114 240-246

Buch JP, Lipschultz LI and Smith RG (1991) Evidence for altered receptorbinding activity of serum follicle stimulating hormone in male infertility Fertility and Sterility 55 358-362

Burger HG, McLachlan RI, Bangah M, Quigg H, Findlay JK, Robertson DM, de Kretser DM, Warne GL, Werther GA, Hudson IL, Cook J], Fiedler R, Greco S, Young ABW and Smith $P$ (1988) Serum inhibin concentrations rise throughout normal male and female puberty Journal of Clinical Endocrinology and Metabolism 68 689-695

Cailleau J, Vermeire S and Verhoeven G (1990) Independent control of the production of insulin-like growth factor I and its binding protein by cultured testicular cells Molecular and Cellular Endocrinology 69 79-89

Casella SJ, Smith EP, van Wyk JJ, Joseph DR, Hynes MA, Hoyt EC and Lund PK (1987) Isolation of rat testis cDNAs encoding an insulin-like growth factor I precursor DNA 6 325-330

Chatelain P, Perrard-Sapori MH, Jaillard C, Naville D, Ruitton A and Saez J (1987) Somatomedin C-insulin-like growth factor I, a differentiating factor of testicular function International Joumal of Radiologic Applications and Instruments [B] 14 617-622

Chen CLC and Madigan M (1987) Regulation of testicular proopiomelanocortinlike gene expression Endocrinology 121 590-596

Chen CLC, Mather JP, Morris PL and Bardin CW (1984) Expression of proopiomelanocortin-like gene in the testis and epididymis Proceedings of the National Academy of Sciences USA $815672-5675$

Cheng CY and Bardin C (1987) Identification of two testosterone-responsive testicular proteins in Sertoli cell enriched culture medium whose secretion is suppressed by cells of the intact seminiferous tubule Journal of Biological Chemistry 26212 768-12 779

Cheng CY, Grima J, Lee WM and Bardin CY (1987) The distribution of rat testibumin in the male reproductive tract Biology of Reproduction 37 875-885

Cheng CY, Chen CL, Feng ZM, Marshall A and Bardin CW (1988) Rat clusterin isolated from primary Sertoli cell enriched culture medium is sulfated glycoprotein-2 (SGP-2) Biochemical and Biophysical Research Communications 155 398-406

Closset J, Gothot A, Sente B, Scippo ML, Igout A, Vandenbroeck M, Dombrowicz D and Hennen G (1989) Pituitary hormone dependent expression of insulinlike growth factors I and II in the immature hypophysectomised rat testis Molecular Endocrinology 3 1125-1131

Collard M and Griswold MD (1987) Biosynthesis and molecular cloning of sulfated glycoprotein 2 secreted by rat Sertoli cells Biochemistry 26 3297-3303

Collard M, Sylvester SR, Tsuruta JK and Griswold MD (1988) Biosynthesis and molecular cloning of sulfated glycoprotein 1 secreted by rat Sertoli cells: sequence similarity with the 70 -kilodalton precursor to sulfatide/ $\mathrm{GmI}$ activator Biochemistry 27 4557-4564

Conti M, Culler MD and Negro-Villar A (1988) Adenosine receptor-dependent modulation of inhibin secretion in cultured immature rat Sertoli cells Molecular and Cellular Endocrinology 59 255-259

Culler MD and Negro-Villar A (1988) Passive immunoneutralisation of endogenous inhibin, sex-related differences in the role of inhibin during development Molecular and Cellular Endocrinology 58 263-273

D'Ercole AJ, Stiles AD and Underwood LE (1984) Tissue concentrations of somatomedin C: further evidence of multiple sites of synthesis and paracrine or autocrine mechanisms of action Proceedings of the National Academy of Sciences USA $81935-939$

Dave JR, Bisserbe IC and Eskay RL (1984) Specific binding sites for corticotrophin-releasing factor in rat peripheral tissues and their modulation in vitro by ethanol Proceeding of the 7th International Congress of Endocrinology Abstract 512. Excerpta Medica, Amsterdam

de Jong FH and Robertson DM (1985) Inhibin: 1985 update on action and purification Molecular and Cellular Endocrinology 42 95-103

de Kretser DM, McLachlan RI, Robertson DM and Burger HG (1989) Serum inhibin levels in normal men and men with testicular disorders Journal of Endocrinology 120 517-523

de Paolo LV, Bicsak TA, Erikson GF, Shimasaki S and Ling N (1991) Follistatin and activin: a potential intrinsic regulatory system within diverse tissues Proceedings of the Society of Experimental Biology and Medicine $198500-512$ 
Deschepper CF, Mellon SH, Cumin F, Baxter JD and Ganong WF (1986) Analysis by immunocytochemistry and in situ hybridisation of renin and its mRNA in kidney, testis, adrenal, and pituitary of the rat Proceedings of the National Academy of Sciences USA 83 7552-7558

Deuel TF (1987) Polypeptide growth factors: roles in normal and abnormal growth Annual Review of Cell Biology 3 443-492

de Winter JP, Themmen APN, Hoogerbrugge JW, Klaij IA, Grootegoed JA and de Jong FH (1992) Activin receptor mRNA expression in rat testicular cell types Molecular and Cellular Endocrinology 83 RI-R8

Dias JA and Reichert LE, Jr (1983) Evidence for the presence of a large molecular weight factor in bovine testis which inhibits binding of FSH to its receptor Joumal of Andrology 2 259-268

Dias IA, Treble DH, Bennet AH and Reichert LE, Jr (1981) Follicle stimulating hormone receptor binding inhibitors in human seminal plasma Journal of Andrology 2 259-268

Djakiew D, Hadley MA, Byers SW and Dym M (1986) Transferrin-mediated transcellular transport of ${ }^{59} \mathrm{Fe}$ across confluent epithelial sheets of Sertoli cells grown in dual environment culture chambers Journal of Andrology 7 355-366

Douglass I, Cox B, Quinn B, Civelli O and Herbert E (1987) Expression of the prodynorphin gene in male and female mammalian reproductive tissues Endocrinology 120 707-713

Downward I, Yarden Y, Mayes E, Scrace G, Totty N, Stockwell P, Ullich A, Schlessinger $J$ and Waterfield MD (1984) Close similarity of epidermal growth factor receptor and v-erb oncogene protein sequences Nature $\mathbf{3 0 7}$ $521-527$

Elson D, Browne CA and Thorburn GD (1984) Identification of epidermal growth factor-like activity in human male reproductive tissues and fluids Joumal of Clinical Endocrinology and Metabolism 58 589-594

Engelhardt RP (1989) Opioides gonadiques et fonction testiculaire Annales d'Endocrinologie 50 64-72

Engelhardt RP, Saint-Pol P, Tramu G and Leonardelli J (1986) Immunohistochemical localisation of enkephalin-like peptides during testicular development in rats Archives of Andrology 17 49-56

Erickson-Lawrence M, Zabludoff SD and Wright WW (1990) Cyclic protein-2, a secretory product of rat Sertoli cells, is the proenzyme form of cathepsin L Journal of Cellular Biology 111 107a

Fabbri A, Knox G, Buczko E and Dufau ML (1988) Beta-endorphin production by the fetal Leydig cell: regulation and implications for paracrine control of Sertoli cell function Endocrinology 122 749-755

Fabbri A, Jannini EA, Gnessi L, Ulisse S, Moretti C and Isidori A (1989) Neuroendocrine control of male reproductive function. The opioid system as a model of control at multiple sites Journal of Steroid Biochemistry 32 145-150

Fauser BCIM, Bogers JW, Hop WCJ and de Jong FH (1990) Bioactive and immunoreactive FSH in serum of normal and oligospermic men Clinical Endocrinology 32 433-442

Foo NC, Carter D, Murphy D and Ivell R (1991) Vasopressin and oxytocin gene expression in rat testis Endocrinology 128 2118-2128

Franchimont P, Croze F, Demoulin A, Bologne R and Hustin J (1981) Effect of inhibin in rat testicular deoxyribonucleic acid (DNA) synthesis in vitro Acta Endocrinologica 98 312-320

Fujisawa M, Bardin CW and Morris PL (1992) A germ cell factor(s) modulates preproenkephalin gene expression in rat Sertoli cells Molecular and Cellular Endocrinology 84 79-88

Gerendai I, Shaha C, Gunsalus G and Bardin CW (1986) The effects of opioid receptor antagonists suggest that testicular opiates regulate Sertoli and Leydig cell function in the neonatal rat Endocrinology 117 2039-2044

Gizang-Ginsberg E and Wolgemuth DJ (1985) Localisation of mRNAs in the mouse testes by in situ hybridisation, distribution of alpha-tubulin and developmental stage specificity of pro-opiomelanocortin transcripts Developmental Biology $111293-305$

Gizang-Ginsberg E and Wolgemuth DJ (1987) Expression of the proopiomelanocortin gene is developmentally regulated and affected by germ cells in the male mouse reproductive system Proceedings of the National Academy of Sciences USA 84 1600-1604

Gonzales GF, Risbridger GP and de Kretser DM (1988) In vitro synthesis and release of inhibin in response to FSH stimulation by isolated segments of seminiferous tubules from normal adult male rats Molecular and Cellular Endocrinology 59 179-185

Gonzales GF, Risbridger GP, Hodgson YH, Pollanen P and de Kretser D (1989) Stage-specific inhibin secretion by rat seminiferous tubules Reproduction, Fertility and Development 1 275-279
Guldenaar SFF and Pickering BT (1985) Immunohistochemical evidence for the presence of oxytocin in rat testis tissue Cell and Tissue Research $\mathbf{2 4 0}$ 485-487

Hamilton DW and Waites GMH (1989) Cellular and molecular events in spermiogenesis. In Scientific Basis of Fertility Regulation Cambridge University Press, Cambridge

Handelsman DJ, Spaliviero JA, Scott CD and Baxter RC (1985a) Identification of insulin-like growth factor-I and its receptors in the rat testis Acta Endocrinologica $109543-549$

Handelsman DJ,Sspaliviero JA, Scott CD and Baxter RC (1985b) Identification of insulin-like growth factor-I and its receptors in the rat testis Acta Endocrinologica 109 543-549

Hansson HA, Billig $\mathrm{H}$ and Isgaard J (1989) Insulin-like growth factor I in the developing and mature rat testis: immunohistochemical aspects Biology of Reproduction 40 1321-1328

Hettle JA, Waller EK and Fritz IB (1986) Hormonal stimulation alters the type of plasminogen activator produced by Sertoli cells Biology of Reproduction 34 895-904

Hettle JA, Balekjian EN, Tung PS and Fritz IB (1988) Rat testicular peritubular cells in culture secrete an inhibitor of plasminogen activator activity Biology of Reproduction 38 359-371

Holmes SD, Bucci LR, Lipschultz LI and Smith RG (1983) Transferrin binds specifically to pachytene spermatocytes Endocrinology 113 1916-1918

Ivell R (1992) "All that glisters is not gold" - common testis gene transcripts are not always what they seem International journal of Andrology 15 85-92

Ivell $\mathbf{R}$ and Morley $\mathbf{S}$ (1988) Neuropeptide gene expression in mammalian ovary and testis. In Carl Schirren Symposium: Advances in Andrology, pp 198-203 Eds AF Holstein, F Leidenberger, KH Holzer and G Bettendorf. Diesenbach Verlag, Berlin

Ivell R, Schmale H, Kirsch B, Nahke P and Richter D (1986) Expression of a mutant vasopressin gene: differential polyadenylation and read-through of the mRNA 3'end in a frame-shift mutation EMBO journal 5 971-977

Jaiswal AK, Panda JN, Kumar MV and Joshi P (1985) Androgen dependence of testicular and epididymal angiotensin converting enzyme Andrologia 17 92-97

Janecki A, Jakubowiak A and Steinberger A (1988) FSH and testosterone differentially regulate bidirectional secretion of inhibin and FSH stimulating activity in cultures of immature rat Sertoli cells Joumal of Andrology 927 (Abstract)

Jeanotte L, Burbach JPH and Drouin J (1987) Unusual proopiomelanocortin ribonucleic acids in extrapituitary tissues: intronless transcripts in testes and long poly $(\mathrm{A})$ tails in hypothalamus Molecular Endocrinology $1749-757$

Jockenhövel F, Khan SA and Nieschlag E (1990) Varying dose-response characteristics of different immunoassays and an in vitro bioassay for follicle stimulating hormone are responsible for changing ratios of biologically active to immunologically active follicle stimulating hormone joumal of Endocrinology $127523-532$

Kaipia A, Parvinen M, Shimasaki S, Ling N and Toppari J (1991) Stage-specific regulation of inhibin $\alpha$-subunit mRNA expression in the rat seminiferous epithelium Molecular and Cellular Endocrinology 82 165-173

Kaipia A, Penttila TL, Parvinen M, Shimasaki S, Ling N and Toppari J (1992) Expression of inhibin $\beta \mathrm{B}$ mRNA in the rat seminiferous epithelium. Miniposter 72. In Proceedings of the 7th European Workshop on Molecular and Cellular Endocrinology of the Testis, May 5-10, 1992, Castle Elmau, Germany

Kangasniemi M, Cheng CY, Toppari J, Grima J, Stahler M, Kaipia A, Bardin CW and Parvinen M (1992) Basal and FSH-stimulated steady state levels of SGP$2, \alpha_{2}$-macroglobulin and testibumin in culture media of rat seminiferous tubules at defined stages of the epithelial cycle Journal of Andrology 13 208-213

Kasson BG and Hsueh (1987) Insulin-like growth factor I augments gonadotrophin stimulated androgen biosynthesis by cultured rat testicular cells Molecular and Cellular Endocrinology 52 27-34

Kasson BG, Adashi EY and Hsueh AJW (1986) Arginine vasopressin in the testis: an intragonadal peptide control system Endocrine Reviews 7 156-168

Keeping HS, Winters SI, Attardi B and Troen P (1990) Developmental changes in testicular inhibin and androgen binding protein during sexual maturation in the cynomologous monkey, Macaca fascicularis Endocrinology 126 2858-2867

Keinan D, Madigan MB, Bardin CW and Chen CLC (1989) Expression and regulation of testicular $\alpha$-subunit inhibin gene in vivo and in vitro Molecular Endocrinology $329-35$

Kew D and Kilpatrick DL (1989) Expression and regulation of the proenkephalin gene in rat Sertoli cells Molecular Endocrinology 3 179-184 
Kilpatrick DL and Milette CF (1986) Expression of proenkephalin messenger RNA by mouse spermatogenic cells Proceedings of the National Academy of Sciences USA 83 5015-5018

Kilpatrick DL, Borland K and Jin DF (1987) Differential expression of opioid peptide genes by testicular germ cells and somatic cells Proceedings of the National Academy of Sciences USA 84 5695-5699

Kissinger C, Skinner MK and Griswold MD (1982) Analysis of Sertoli cell secreted proteins by two-dimensional electrophoresis Biology of Reproduction $27233-240$

Klaij IA, Toebosch AMW, Themmen APN, Shimasaki S, de Jong FH and Grootegoed JA (1990) Molecular and Cellular Endocrinology 68 45-52

Kris RM, Lax I, Gullick W, Waterfield MD, Ullrich A, Fridkin M and Schlessinger J (1985) Antibodies against a synthetic peptide as a probe for the kinase activity of the avian EGF receptor and v-erbB protein Cell 40 619-625

Kwan TK and Grover DB (1988) Inhibition of rat testicular microsomal steroidogenesis by oxytocin and metyrapone Biochemistry Intemational 16 629-637

Lacroix M and Fritz IB (1982) The control of the synthesis and secretion of plasminogen activator by rat Sertoli cells in culture Molecular and Cellular Endocrinology 26 247-258

Leblond CP and Clermont Y (1952) Definition of the stages of the cycle of the seminiferous epithelium in the rat Annals of the New York Academy of Sciences 55 548-573

Lee W, Mason AJ, Schwall R, Szonyi E and Mather JP (1989) Secretion of activin by interstitial cells in the testis Science 243 396-398

LeGac $\mathbf{F}$ and de Kretser DM (1982) Inhibin production by Sertoli cell cultures Molecular and Cellular Endocrinology 28 487-498

Lin T, Haskell J, Vinson N and Terracio L (1986) Direct stimulatory effects of insulin-like growth factor I on Leydig cell steroidogenesis in primary culture Biochemical and Biophysical Research Communications 137 950-956

Lin T, Blaisdell J and Haskell JF (1988) Hormonal regulation of type I insulinlike growth factor receptors of Leydig cells in hypophysectomised rats Endocrinology 123 134-139

Ling N, Ying SY, Ueno N, Shimasaki S, Hotta M and Guillemin SR (1986) Pituitary FSH is released by a heterodimer of the $\beta$-subunits from the two forms of inhibin Nature 321 779-782

McCullagh DR (1932) Dual endocrine activity of the testis Science 76 19-20

McLachlan RI, Dahl KD, Bremner WJ, Schwall R, Schmeizer CH, Mason AJ and Steiner RA (1989) Recombinant human activin A stimulates basal FSH and GnRH stimulated FSH and LH release in the male macaque, Macaca fascicularis Endocrinology 125 2787-2789

McMurray CT, Devi L, Calavetta L and Douglass JO (1989) Regulated expression of the prodynorphin gene in the R2C Leydig tumur cell line Endocrinology 124 49-59

Maddocks S and Sharpe RM (1989) The route of secretion of inhibin from the rat test is Joumal of Endocrinology 120 R5-R8

Maddocks S and Sharpe RM (1990) The effects of sexual maturation and altered steroid synthesis on the production and route of secretion of $\alpha$-inhibin from the rat testis Endocrinology 126 1541-1550

Mallea LE, Machado AJ, Navaroli F and Rommerts FFG (1986) Epidermal growth factor stimulates lactate production and inhibits aromatization in cultured Sertoli cells from immature rats Joumal of Andrology 9 201-208

Mather JP and Krummen LA (1992) Inhibin, activin and growth factors: paracrine regulators of testicular function. In Spermatogenesis, Fertilization, Contraception: Molecular, Cellular and Endocrine Events in Male Reproduction, pp 169-201 Eds E Nieschlag and UF Habenicht. Springer Verlag, Berlin

Mather JP, Attie K, Rice G and Phillips D (1990) Activin stimulates spermatogonial proliferation in Sertoli-germ cell co-cultures from immature rat testis Endocrinology 127 3206-3214

Mathews LS and Vale WW (1991) Expression cloning of an activin receptor, a predicted transmembrane serine kinase Cell 65 973-982

Matzkin H, Homonnai ZT, Galiani D, Paz G and Dekel N (1990) Serum bioactive and immunoreactive follicle stimulating hormone in oligozoospermic and azoospermic men, application of a modified granulosa cell bioassay Fertility and Sterility 53 709-714

Merchenthaler I, Culler MD, Petrusz P and Negro-Vilar A (1987) Immunocytochemical localization of inhibin in rat and human reproductive tissues Molecular and Cellular Endocrinology 54 239-243

Millan MA and Aguilera G (1988) Angiotensin II receptors in testes Endocrinology 122 1984- 1990

Mita M, Borland K, Price JM and Hall PF (1985) The influence of insulin and insulin-like growth factor-I on hexose transport by Sertoli cells Endocrinology $116987-992$
Morales C, Sylvester SR and Griswold MD (1987) Transport of iron and transferrin synthesis by the seminiferous epithelium of the rat in vivo Biology of Reproduction 37 995-1005

Morgan DO, Edman JC, Standring DN, Fried VA, Smith MC, Roth RA and Rutter WJ (1987) Insulin-like growth factor II receptor as a multi-functional binding protein Nature $329301-307$

Morris PL and Mather JP (1984) Epidermal growth factor binding sites in testicular cells Federation Proceedings 43 522-529

Morris PL, Vale WW, Cappel S and Bardin CW (1988) Inhibin production by primary Sertoli-cell-enriched cultures: regulation by follicle stimulating hormone, androgens and epidermal growth factor Endocrinology $\mathbf{1 2 2}$ $717-725$

Mullaney BP, Glenn B and Skinner MK (1991) Cell-cell interactions in the testis: the role of transforming growth factors Biology of Reproduction 44182 Abstract 520

Murphy LJ, Bell GI and Friesen HG (1987) Tissue distribution of insulinlike growth factor I and II messenger ribonucleic acid in the adult rat Endocrinology 120 1279-1282

Nagpal ML, Wang D, Calkins JH, Chang W and Lin T (1991) Human chorionic gonadotropin up-regulates insulin-like growth factor-I receptor gene expression of Leydig cells Endocrinology 129 2820-2826

Namiki M, Koide T, Okuyama A, Sonoda T, Itatani H, Miyake A, Aono T, Terada N and Matsumoto K (1984) Abnormality of testicular FSH receptors in infertile men Acta Endocrinologica 106 548-555

Nargolwalla C, McCabe D and Fritz IB (1990) Modulation of messenger RNA for tissue type plasminogen activator in rat Sertoli cells, and levels of messenger RNA for plasminogen activator inhibitor in testis peritubular cells Molecular and Cellular Endocrinology 70 73-80

Naruse K, Murakoshi M, Osamura RY, Naruse M, Toma H, Watanabe K, Demura H, Inagami T and Shizume K (1985) Immunohistological evidence for renin in human endocrine tissues Joumal of Clinical Endocrinology and Metabolism 61 172-177

Nicholson HD, Worley RTS, Charlton HM and Pickering BT (1986) LH and testosterone cause the development of seminiferous tubule contractile activity and the appearance of testicular oxytocin in hypogonadal mice Journal of Endocrinology 110 159-167

Nicholson HD, Worley RTS, Guldenaar SEF, Boer GJ and Pickering BT (1987) Ethan-1,2-dimethanesulphonate reduces testicular oxytocin content and seminiferous tubule movements in the rat Joumal of Endocrinology 112 311-316

Nicholson HD, Guldenaar SEF, Boer GJ and Pickering BT (1991) Testicular oxytocin: effects of intratesticular oxytocin in the rat Joumal of Endocrinology $130231-238$

Norton JN and Skinner MK (1989) Regulation of Sertoli cell differentiation through the actions of a testicular paracrine factor P-Mod-S Endocrinology 124 2711-2719

O'Brien DA, Gable CA and Eddy BM (1988) Mannose 6-phosphate receptor mediated endocytosis in isolated mouse spermatogenic cells Biology of Reproduction 38 (Supplement 1) 141 Abstract

Okuyama A, Nakamura M, Namiki M, Takeyama M, Fujioka H, Matsuda M, Matsumoto $K$ and Sonoda $T$ (1988) Demonstration of gonadotrophininduced plasma renin activity in human internal spermatic vein Acta Endocrinologica 117 268-272

Oonk, RB (1987) Effects of FSH, insulin and IGF-i on rat Sertoli cells. In Proefschrift, pp 1-159. Erasmus University, Rotterdam

Oonk RB and Grootegoed JA (1988) Insulin-like growth factor-I (IGF-I) receptors on Sertoli cells from immature rats and age dependent testicular binding of IGF-I and insulin Molecular and Cellular Endocrinology 55 33-43

Oonk RB, Grootegoed JA and van der Molen HJ (1985) Comparison of the effects of insulin and follitropin on glucose metabolism by Sertoli cells from immature rats Molecular and Cellular Endocrinology 42 39-48

O'Shaughnessy PJ (1979) Age-dependent differences in testicular inactivation of FSH and in inhibition of FSH binding to rat testis Biology of Reproduction 20 1009-1014

Pandey KN, Melner MH, Parmentier N and Inagami T (1984) Demonstration of renin activity in purified rat Leydig cells: evidence for the existence of an endogenous inactive (latent) form of enzyme Endocrinology 115 1753-1759

Parmentier M, Inagami T, Pochet R and Desclin JC (1983) Pituitary-dependent renin-like immunoreactivity in the rat testis Endocrinology 112 1318-1323

Pekary AE and Rosen JI (1982) Gossypol inhibits spermatogenesis but not interstitial cell biosynthesis and Sertoli cell degradation of TRH Clinical Research 32 Abstract 32A 
Pekary AE, Bhasin S, Smith V, Sugawara M, Swerdloff RS and Hershman JM (1987) Thyroid hormone modulation of thyrotropin-releasing hormone (TRH) and TRH-Gly levels in the male rat reproductive system Journal of Endocrinology $114271-277$

Perez-Infante V, Bardin CW, Gunsalus GL, Musto NA, Rich KA and Mather JP (1986) Differential regulation of testicular transferrin and androgen-binding protein secretion in primary cultures of rat Sertoli cells Endocrinology 118 383-393

Pineau C, Sharpe RM, Saunders PTK, Gerard N and Jegou B (1990) Regulation of Sertoli cell inhibin production and of inhibin $\alpha$-subunit mRNA levels by specific germ cell types Molecular and Cellular Endocrinology 72 13-22

Pomerantz DK, Jansz GF and Wilson N (1988) Disruption of spermatogenesis is associated with decreased concentration of immunoreactive arginine vasopressin in testicular fluid Biology of Reproduction 39 610-616

Richards RC, Iwan Lewis-Jones D, Walker JM and Desmond AD (1988) Epidermal growth factor (urogastrone) in human seminal plasma from fertile and infertile males Fertility and Sterility 50 640-643

Risbridger G, Kerr J and de Kretser D (1989) Differential effects of the destruction of Leydig cells by administration of ethane dimethane sulphonate to postnatal rats Biology of Reproduction 40 801-809

Rivier C, Cajander S, Vaughan J, Hsueh AJW and Vale W (1988) Age-dependent changes in physiological action, content and immunostaining of inhibin in male rats Endocrinology 123 120-126

Roberts V, Meunier H, Sawchenko PE and Vale W (1989) Differential production and regulation of inhibin subunits in rat testicular cell types Endocrinology 125 2350-2359

Roberts KP, Awoniyi CA, Santulli R and Zirkin BR (1991) Regulation of Sertoli cell transferrin and sulfated glycoprotein-2 messenger ribonucleic acid levels during the restoration of spermatogenesis in the adult hypophysectomized rat Endocrinology 129 3417-3423

Robertson DM, Prisk M, McMaster JW, Irby DC, Findlay JK and de Kretser DM (1991) Serum FSH-suppressing activity of human recombinant inhibin A in male and female rats Journal of Reproduction and Fertility 91 321-328

Rojas FJ, Moretti-Rojas I, de Bellabarba G and Bishop W (1981) Inhibition of ${ }^{I 25}$ I!-labelled human chorionic gonadotrophin binding to gonadal receptors by a factor obtained from rat testicular tissue Biology of Reproduction 25 519-529

Roth RA (1988) Structure of the receptor for IGF-II: the puzzle amplified Science $2391269-1271$

Russell LD, Weiss T, Goh JC and Curl JL (1990) The effects of submandibular gland removal on testicular and epididymal parameters Tissue and Cell $\mathbf{2 2}$ 263-268

Saez JM, Chatelain PG, Perrard-Sapori, Jaillard C and Naville D (1988) Differentiating effects of somatomedin-C/insulin-like growth factor I and insulin on Leydig and Sertoli cell functions Reproduction, Nutrition, Development 28 989-1008

Saint Pol P, Peyrat PJ, Engelhardt RP and Leroy-Martin B (1986) Immunohistochemical localization of enkephalins in adult rat testis: evidence for gonadotrophin control Andrologia 18 485-488

Saint-Pol P, Herman E and Tramu G (1988) Paracrine factors in the adult rat testis: gonadotrophin control of opioids and LHRL-like peptide Andrologia $19419-422$

Savage CR, Inagami T and Cohen S (1972) The primary structure of epidermal growth factor Joumal of Biological Chemistry 247 7612-7621

Schmale $\mathbf{H}$ and Richter D (1984) Single base deletion in the vasopressin gene is the cause of diabetes insipidus in Brattleboro rats Nature 308 705-709

Schwall R, Schmelzer CH, Matsuyama E and Mason AJ (1989) Multiple actions of recombinant activin $A$ in vivo Endocrinology 123 1420-I423

Sealey JE, Goldstein M, Pitarresi T, Kudlak TT, Glorioso N, Fiamengo SA and Laragh JH (1988) Prorenin secretion from human testis: no evidence for secretion of active renin or angiotensin Journal of Clinical Endocrinology and Metabolism 66 974-978

Shaha C, Morris PL, Chen CLC, Vale W and Bardin CW (1989) Immunostainable inhibin subunits are in multiple types of testicular cells Endocrinology 125 1941-1950

Sharpe RM (1986) Paracrine control of the testis Clinical Endocrinology and Metabolism 15 185-207

Sharpe RM (1990) Intratesticular control of steroidogenesis Clinical Endocrinology 33 787-807

Sharpe RM and Cooper I (1987) Comparison of the effect on purified Leydig cells of four hormones (oxytocin, vasopressin, opiates and LHRH) with suggested paracrine roles in the testis Journal of Endocrinology 113 89-96
Shimasaki S, Koba A, Mercado M, Shimonala M and Ling N (1989) Complementary DNA structures of the high molecular weight insulin-like growth factor binding protein (IGFBP-3) and tissue distribution of its mRNA Biochemical and Biophysical Research Communications 165 907-912

Shimasaki S, Uchiyama F, Shimonaka M and Ling N (1990) Molecular cloning of the cDNAs encoding a novel insulin-like growth factor-binding protein from rat and human Molecular Endocrinology 90 1451-1458

Shimasaki S, Shimonaka $M$, Zhang HP and Ling $N$ (1991) Identification of five different insulin-like growth factor binding proteins (IGFBPs) from adult rat serum and molecular cloning of a novel IGFBP-5 in rat and human Joumal of Biological Chemistry $26610646-10653$

Singh US, Kumar MV and Panda JN (1987) Changes in angiotensin converting enzyme in testes and epididymes of rat due to serotonin administration Andrologia 19 153-156

Skinner MK (1991) Cell-cell interactions in the testis Endocrine Reviews 12 45-77

Skinner MK and Griswold MD (1982) Secretion of testicular transferrin by cultured Sertoli cells is regulated by hormones and retinoids Biology of Reproduction 27 211-221

Skinner MK and Griswold MD (1983) Sertoli cells synthesize and secrete a caeruloplasmin-like protein Biology of Reproduction 28 1225-1229

Skinner MK and Moses HL (1989) Transforming growth factor $\beta$ gene expression and action in the seminiferous tubule, peritubular cell-Sertoli cell interactions Molecular Endocrinology 3 625-634

Skinner MK, Takacs K and Coffey RJ (1989) Transforming growth factor-alpha gene expression and action in the seminiferous tubule: peritubular cell-Sertoli cell interactions Endocrinology 124 845-854

Slaughter GR, Meistrich ML and Means AR (1989) Expression of mRNAs for calmodulin, actins and tubulins in rat testis cells Biology of Reproduction $\mathbf{4 0}$ 395-405

Smith EP, Svoboda ME, Van Wyk JJ, Kierszenbaum AL and Tres LL (1987) Partial characterisation of a somatomedin-like peptide from the medium of cultured rat Sertoli cells Endocrinology 120 186-193

Smith EP, Dickson BA and Chernausek SD (1990) Insulin-like growth factor binding protein from cultured rat Sertoli cells: dual regulation by follicle stimulating hormone and insulin-like growth factor-I Endocrinology 127 2744-2751

Spaliviero JA and Handelsman DJ (1991) Effect of epidermal and insulin-like growth factors on vectorial secretion of transferrin by rat Sertoli cells in vitro Molecular and Cellular Endocrinology 81 95-104

Spiteri-Grech J, Bartlett JMS and Nieschlag E (1991a) Hormonal regulation of intratesticular insulin-like growth factor I and epidermal growth factor in adult male hypophysectomized rats treated with ethane dimethane sulphonate Journal of Endocrinology 129 109-117

Spiteri-Grech J, Bartlett JMS and Nieschlag E (1991b) Regulation of testicular insulin-like growth factor-I in pubertal growth hormone deficient male rats Journal of Endocrinology 131 279-285

Spiteri-Grech J, Weinbauer GF, Bolze P, Chandolia RK, Bartlett JMS and Nieschlag E (1992) Effects of FSH and testosterone on intratesticular IGF-I and specific germ cell populations in rats treated with a $\mathrm{GnRH}$ antagonist Joumal of Endocrinology (in press)

Sporn MB and Roberts AB (1990) The transforming growth factor- $\beta$ s: past, present and future. In Transforming Growth Factor- $\beta$ s: Chemistry, Biology and Therapeutics Eds KA Piez and MB Sporn Annals of the New York Academy of Sciences 593 1-6

Stahler MS, Schlegel P, Bardin CW, Silvestrini B and Cheng CY (1991) $\alpha_{2}$ Macroglobulin is not an acute phase protein in the rat testis Endocrinology 128 2805-2814

Strittmater SM and Synder SH (1984) Angiotensin-converting enzyme in the male reproductive system: autoradiographic visualisation with $\left[{ }^{3} \mathrm{H}\right]$ captopril Endocrinology 115 2332-2341

Stubbs SC, Hargreave TB and Habib FK (1990) Localization and characterization of epidermal growth factor receptors on human testicular tissue by biochemical and immunohistochemical techniques Joumal of Endocrinology 125 485-492

Suarez-Quian CA, Dai M, Onoda M, Kriss RM and Dym M (1989) Epidermal growth factor receptor localisation in the rat and monkey testis Biology of Reproduction 41 921-932

Syed V, Khan SA and Nieschlag E (1991) Epidermal growth factor stimulates testosterone production in human Leydig cells in vitro Joumal of Endocrinological Investigation 14 93-97

Sylvester SR, Skinner MK and Griswold MD (1984) A sulfated glycoprotein synthesized by Sertoli cells and by epididymal cells is a component of the sperm membrane Biology of Reproduction 31 1087-1101 
Sylvester SR, Morales C, Oko R and Griswold MD (1991) Localization of sulfated glycoprotein- 2 (clusterin) on spermatozoa and in the reproductive tract of the male rat Biology of Reproduction 45 195-207

Tan GJS and Kwan TK (1987) Effect of oxytocin on plasma testosterone levels in the male macaque (Macaca fascicularis) Contraception 36 359-367

Taylor JE, Scott CD and Baxter RC (1987) Comparison of receptors for insulinlike grow th factor II from various rat tissues Joumal of Endocrinology 115 35-4I

Teerds KJ and Dorrington JH (1992) Localization of TGF- $\beta 1$ and TGF- $\beta 2$ in the rat testis. Miniposter 80 In Proceedings of the 7th European Workshop on Molecular and Cellular Endocrinology of the Testis, May 5-10, 1992. Castle Elmau, Germany

Toebosch AMW, Kroos MJ and Grootegoed JA (1987) Transport of transferrinbound iron into rat Sertoli cells and spermatids International Journal of Andrology 10 753-764

Toebosch AMW, Robertson DM, Trapman J, Klaassen P, De Pauss RA, De Jong FH and Grootegoed JA (1988) Effects of FSH and IGF-I in immature rat Sertoli cells, inhibin $\alpha$ - and $\beta$-subunit mRNA levels and inhibin secretion Molecular and Cellular Endocrinology 55 101-105

Trasler JM, Alcivar AA, Awoniyi CA, Santulli R, Zirkin BR and Hecht NB (1992) Temporal gene expression is restored concomitantly with germ cells in the experimentally regressed rat testis Endocrinology 131 297-304

Tres LL, Smith EP, Van Wyck JJ and Kierszenbaum AL (1986) Immunoreactive sites and accumulation of somatomedin-C in rat Sertoli-spermatogenic cell co-cultures Experimental Cell Research 162 33-50

Tsonis CG and Sharpe RM (1986) Dual gonadal control of follicle stimulating hormone Nature $321724-725$

Tsutsumi O, Kurachi H and Oka T (1986) A physiological role for epidermal growth factor in male reproductive function Science 233 975-977

Valenca M and Negro-Vilar A (1986) Proopiomelanocortin-derived peptides in testicular interstitial fluid: characterization and changes in secretion after human chorionic gonadotropin or luteinizing hormone releasing hormone analog treatment Endocrinology 118 32-37

van Dissel-Emiliani FMF, Grootenhuis AJ, de Jong FH and de Rooij DG (1989) Inhibin reduces spermatogonial numbers in testes of adult mice and chinese hamsters Endocrinology 125 1898-1903

Vanelli BG, Barni T, Orlando C, Natali A, Serio M and Balboni GC (1988) Insulin-like growth factor-I (IGF-I) and IGF-I receptor in human testis: an immunohistochemical study Fertility and Sterility 49 666-669

Velletri PA, Aquilano DR, Bruckwick E, Tsai-Morris CH, Dufau ML and Loverberg $W$ (1985) Endocrinological control and cellular localisation of rat testicular angiotensin-converting enzyme (EC 3.4.15.1) Endocrinology 116 $2516-2522$
Vihko KK, Toppari J and Parvinen M (1987) Stage-specific regulation of plasminogen activator secretion in the rat seminiferous epithelium Endocrinology 120 142-145

Vihko KK, Penttilä TL, Parvinen M and Belin D (1989) Regulation of urokinase and tissue-type plasminogen activator gene expression in the rat seminiferous epithelium Molecular Endocrinology 3 52-59

Vijayalakahmi S, Bandivdekar AH, Joshi LR, Moodbidri SB and Sheth AR (1980) Isolation and characterization of ovine testicular and ovarian inhibin Archives of Andrology 5 179-188

Wagner TOF and von zur Mühlen A (1987) Slow pulsing oligospermia. Treatment by longtime pulsatile LHRH therapy. In Episodic Hormone Secretion: From Basic Science to Clinical Application, pP 197-203 Eds TOF Wagner and $M$ Filicori. TM Verlag, Hammeln

Wagner TOF, Brabant G, Warsch F and von zur Mühlen A (1984) Slow pulsing oligospermia Acta Endocrinologica 105 (Supplement 264) 152 Abstract

Wang C, Dahl KD, Leung A, Chan SYW and Hsueh AJW (1987) Serum bioactive follicle stimulating hormone in men with idiopathic azoospermia and oligospermia Journal of Clinical Endocrinology and Metabolism 65 629-634

Wauben-Penris PJJ, Strous GJ and van der Donk HA (1988) Kinetics of transferrin endocytosis and iron uptake by intact rat isolated seminiferous tubules and Sertoli cells in culture Biology of Reproduction 38 853-861

Wathes DC (1984) Possible actions of gonadal oxytocin and vasopressin Joumal of Reproduction and Fertility 71 315-345

Weinbauer GF, Bartlett JMS, Fingscheidt U, Tsonis CG, de Kretser DM and Nieschlag E (1989) Evidence for a major role in the feedback control of FSH in the male rat Joumal of Reproduction and Fertility 85 355-362

Worley RTS, Nicholson HD and Pickering BT (1985) Testicular oxytocin: an initiator of seminiferous tubule movement? In Recent Progress in Cellular Endocrinology of the Testis Eds JM Saez, MG Forest, A Dazord and J Bertrand. Coloques de l'INSERM 123 205-212. INSERM, Paris

Wright WW and Luzarraga ML (1986) Isolation of cyclic protein-2 from rat seminiferous tubule fluid and Sertoli cell culture medium Biology of Reproduction 35 761-772

Wright WW, Musto NA, Mather JP and Bardin CW (1983) Sertoli cells secrete both testis-specific and serum proteins Proceedings of the National Academy of Sciences USA 78 7565-7569

Yang KP, Samaan NA and Ward DN (1976) Characterization of an inhibitor for luteinizing hormone receptor site binding Endocrinology 98 233-241

Yoon DJ, Sklar C and David R (1988) Presence of immunoreactive corticotrophinreleasing factor in the rat testis Endocrinology 122 759-761

Yoshikawa K and Aizawa T (1988) Expression of the enkephalin precursor gene in rat Sertoli cells: regulation by follicle stimulating hormone FEBS Letters 237 183-186 